\title{
Changes in Plasma Progesterone Levels during the Estrous Cycle and Pregnancy in 4-day Cyclic Mice
}

\author{
Tadashi KOSAKA, Toru R. SAITO** and Kazuaki W. TAKAHASHI* \\ Toxicology Division, Institute of Environmental Toxicology, \\ Suzuki-cho 2-772, Kodaira-shi, Tokyo 187, Japan, and \\ * Department of Laboratory Animal Sciece, Nippon \\ Veterinary \& Zootechnical College, Kyonan-cho \\ 1-7-1, Musashino-shi, Tokyo 180
}

(Received 27 January 1988/Accepted 4 March 1988)

\begin{abstract}
Changes in plasma progesterone levels during the estrous cycle and pregnancy were determined in group-housed IVCS strain mice showing regular 4-day cycles in the absence of a male. The pattern of progesterone secretion during the estrous cycle consisted of a large peak and a small one, the former during the late afternoon of proestrus and the latter on the afternoon of metestrus. From Day 0 to Day 2 of pregnancy, a sharp rise was observed, and then this level reached a plateau. A marked increase in progesterone was shown from Day 13 until the day before parturition.
\end{abstract}

The estrous cycle of laboratory mice has been reported to be influenced by the presence or absence of a male $[5,8,10]$. Absence of a male results in an irregular cycle and/or persistent diestrus. Nobunaga [4] showed that IV CS strain mice, even those housed in a group, exhibit the regularly repeated 4-day estrous cycle in the absence of a male. In the present study, we measured the plasma concentration of progesterone during the estrous cycle and pregnancy in this strain of mice which show the regular 4-day cycles.

A total of 278 virgin female mice (8-12 weeks old) of strain IV CS, bred in our laboratory and showing almost regular 4-day estrous cycles, were used. They were kept in a room at a temperature of $23-25{ }^{\circ} \mathrm{C}$ and exposed to a light-schedule of $14 \mathrm{~h}$ light and $10 \mathrm{~h}$ darkness (lights on at $0500 \mathrm{~h}$ ). They received standard laboratory diet and tap water ad libitum.

After two consecutive 4-day estrous cycles were detected by vaginal smears, the females were assigned to either a cyclic group or a mated (pregnant) group, and times of autopsy were randomly assigned (4-9 animals per time period). On the evening of proestrus, females of the mated group were caged overnight with mature male mice and were inspected for the presence of vaginal plugs on the following morning (Day 0 of pregnancy). Cyclic females were killed at 2 to $4-\mathrm{h}$ intervals throughout the $24-\mathrm{h}$ period from 0900 on the proestrus day through 0900 on the estrus and 2100 on the estrus days, and on a similar time schedule from metestrus to distrus. Pregnant females were killed at daily intervals from Day 0 to Day 19 (day of parturition). Individual blood samples were collected from the vena cava caudalis with a heparinized syringe under ether anesthesia between 0900 and $1000 \mathrm{~h}$. Plasma levels of progesterone were determined by radioimmunoassay by the procedure described previously [6]. The coefficient of variation for intra- and interassay variability were 6.0 and

\footnotetext{
** Present address: Department of Pharmacology, Kyorin University School of Medicine, Mitaka-shi Tokyo 181, Japan
} 


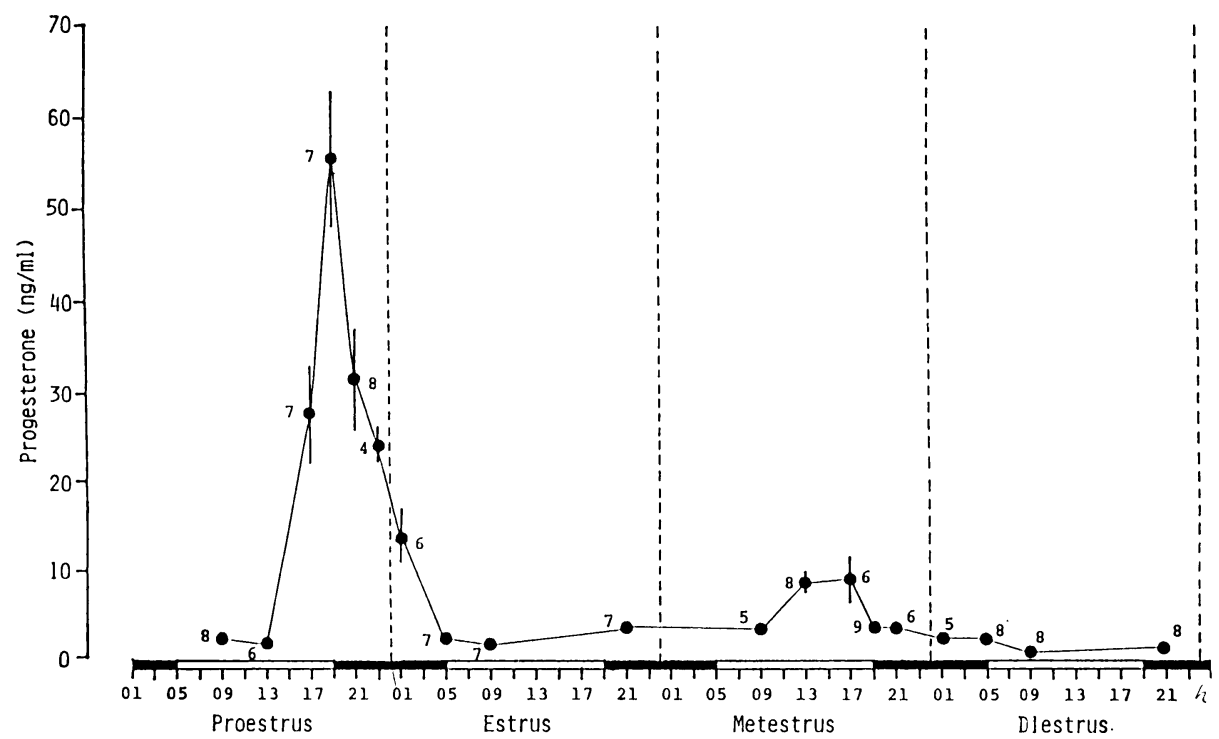

Fig. 1. Plasma progesterone levels during the estrous cycle in the mouse. Values are the mean $\pm \mathrm{SE}$ with the number of replicates. The black bars represent the dark period $(1900-0500 \mathrm{~h})$ and the dashed lines denote midnight

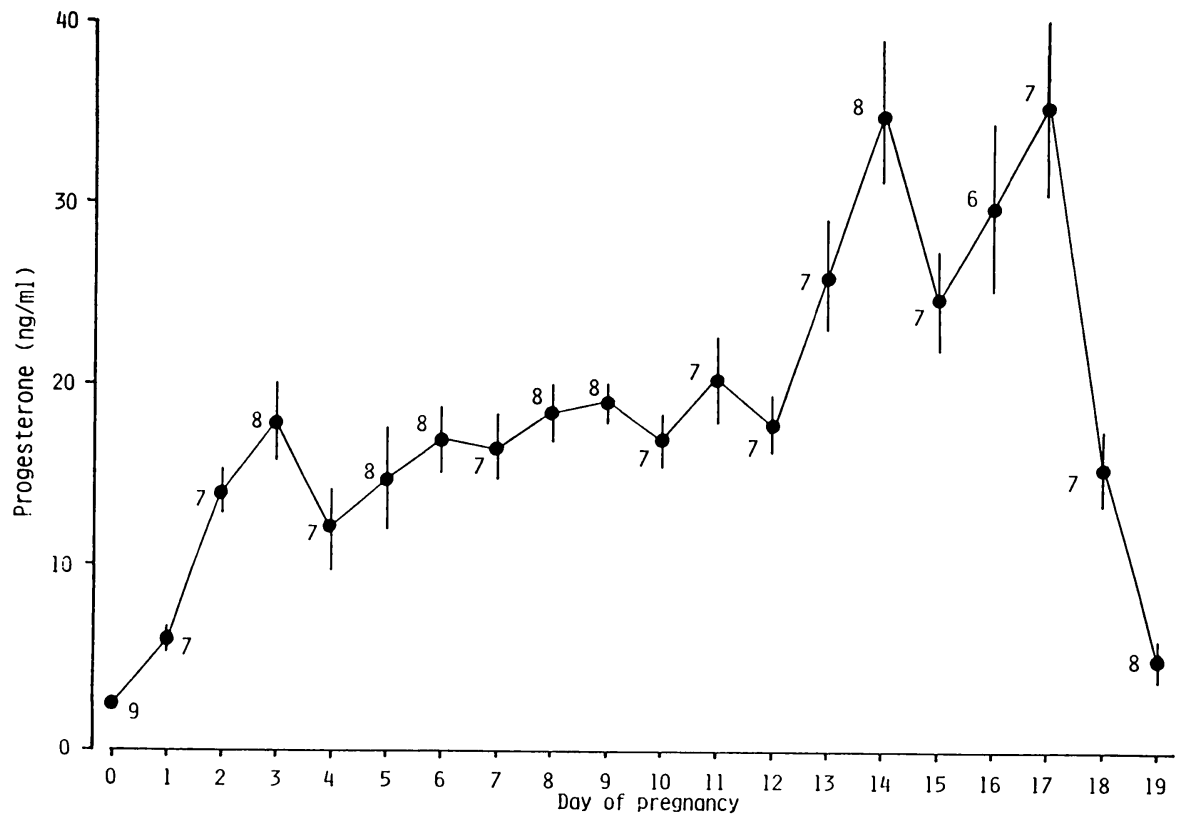

Fig. 2. Plasma progesterone levels during pregnancy in the mouse. Values are the mean $\pm \mathrm{SE}$ with the number of replicates

$12.6 \%$, respectively.

The pattern of progesterone secretion during the estrous cycle is shown in Fig. 1. During the afternoon of proestrus, the progesterone concentration rose to a peak of $55.5 \pm 7.6 \mathrm{ng} / \mathrm{ml}$ (mean $\pm \mathrm{SE}$ ) at $1900 \mathrm{~h}$. This increase over the baseline level was significant $(\mathrm{p}<0.01)$. After $1900 \mathrm{~h}$, the progesterone levels began to decrease, falling to the baseline value by $0500 \mathrm{~h}$ on the day of estrus. The second significant 
increase $(p<0.01)$ occurred at $1300 \mathrm{~h}$ of the metestrus. In these animals, no females had been found to have ovulated when they were examined at $0100 \mathrm{~h}$, and all 7 females had ovulated by $0500 \mathrm{~h}$. The large proestrus peak of progesterone secretion shown here is similar to that which has long been known to occur in the rat [7] and found in mice housed in the presence of a male [5] and in mice of a random-bred stock derived from a 4-way cross, Line $\mathrm{C}[2]$. It was interesting that the increase in progesterone seen in metestrus was less than that in rats and Line $\mathrm{C}$ mice.

Fig. 2 shows the plasma concentrations of progesterone during pregnancy. From Day 0 to Day 2 of pregnancy, there was a sharp and significant increase $(p<0.01)$ to a level which was maintained with some variations until Day 12. On Day 13 the progesterone level increased again. On Day 14 and Day 17 two peak levels, $34.9 \pm 4.4$ and $35.2 \pm 4.7 \mathrm{ng} / \mathrm{ml}$, were found. The concentration on Day 18 was significantly less $(p<0.01)$ than that on Day 17 , and this level was further decreased on Day 19 (day of parturition). There were similar progesterone patterns in our results and in previous studies $[1,3,9]$ which showed a marked increase from midpregnancy until just before parturition.

The authors wish to express their thanks to Dr. Y. Shirasu, Toxicology Division, Institute of Environmental Toxicology, Kodaira, and Dr. T. Nobunaga, Institute of Experimental Animals, Tohoku University School of Medicine, Sendai, for their valuable advice and suggestions.

\section{Reference}

[1] McCormack, J. T., and Greenwald, G. S. (1974). J. Endocrinol., 62, 101-107.

[2] Michael, S. (1976). Proc. Soc. Exp. Biol. Med., 153, 254-257.

[ 3 ] Murr, S. M., Stabenfeldt, G. H., Bradtord, G. E., and Geschwind, I. I. (1974). Endocrinology, 94, 1209-1211.

[4] Nobunaga, T., Takahashi, K. W., and Okamoto, M. T. (1973). Experimental Animals Supplement, 22, 277-287.

[5] Ryan, K. D., and Schwartz, N. B. (1980). Endocrinology, 106, 959-966.

[6] Saito, T. R., Kosaka, T., and Takahashi, K. W. (1982). Jpn. J. Vet. Sci., 44, 125-126.

[7] Smith, M. S., Freeman, M. E., and Neill, J. D. (1975). Endocrinology, 96, 219-226.

[8] Vandenbergh, J. G. (1967). Endocrinology, 81, 345-349.

[9] Virgo, B. B., and Bellward, G. D. (1974). Endocrinology, 95, 1486-1490.

[10] Whitten, W. K. (1956). J. Endocrinol., 13, 399404.

\title{
4 日性周期マウスにおける性周期中および妊娠期間中の
}

\author{
血漿中プロジェステロン濃度変化 \\ 小坂忠司・斎藤徹 ·高橋和 明* \\ (財)残留農薬研究所毒性部 \\ *日本獣医畜産大学実験動物学教室
}

雄の近接なくして規則的な 4 日性周期を回㷌する群飼 育の IVCS 系マウスを用い，性周期中㧍よび妊娠期間中 の血漿中プロジェステロン濃度の変化を検討した。性周 期中のプロジェステロン分泌パターンは, 発情前期の午 後遅くにみられる大きなピークと発情後期の午後にみら
れる小さなピークの $2 つ よ り$ 構成された。妊娠期間中の プロジェステロン濃度では, 妊娠 0 日目より 2 日目にか けて急激な上昇がみられ，その後ほぼ平坦な值を維持し た。また，妊娠13日目より分婏日の前日まで顕著な增加 が認められた。 